\title{
The Brazilian Caatinga in South American zoogeography: tropical mammals in a dry region
}

\author{
MICHAEL A. MARES, MICHAEL R. WILLIG* and THOMAS E. LACHER, Jr $\dagger$ \\ Stovall Museum, University of Oklahoma, Norman, Oklahoma 73019, \\ *Department of Biological Sciences and The Museum, Texas Tech University, Lubbock, \\ Texas 79409, and $\dagger$ Huxley College of Environmental Studies, Western Washington University, \\ Bellingham, Washington 98225, U.S.A.
}

\begin{abstract}
Recent research in South American biogeography on groups other than mammals suggests that the semi-arid Caatinga of northeastern Brazil provided xeric refugia during mesic phases of the Pleistocene climatic cycles. If this supposition is correct, the Caatinga mammal fauna might be expected to contain numerous species showing a pronounced level of adaptation to aridity and the origins of a substantial segment of the fauna should be traceable to the diversification and eventual speciation that would be expected to have resulted from extended isolation in a xeric environment. An analysis of the extant mammal fauna fails to corroborate these predictions; only one endemic mammal species is found in the Caatinga, and the fauna lacks the expected physiological and morphological adaptations. Other vertebrate groups also exhibit low levels of endemism. The high degree of climatic unpredictability that is characteristic of the Caatinga may preclude the development of a unique fauna adapted to xeric conditions. It appears that the present inhabitants of the region avoid the environmental effects of aridity and climatic unpredictability during harsh periods by utilizing the numerous mesic enclaves scattered throughout the Northeast. Indeed, even during periods of elevated precipitation, most mammal species reach their highest density in these relatively restricted areas. Although the Caatinga contains a xeric-adapted flora, it harbours an anomalous mammal fauna that is more characteristic of a mesic tropical biome in terms of both species composition and overall adaptation. The development of an assemblage of vertebrates whose adaptations do not parallel those of the dominant flora in a region is an unusual situation which should be of particular interest to palaeontologists attempting to reconstruct ancient environments.
\end{abstract}

\section{Introduction}

The Neotropical Realm was viewed for many years as a region of long-term climatic stability. Recent evidence suggests that this area has undergone great phytogeographic disruption with attendant effects on speciation patterns. The mechanism generally proposed involves the formation of numerous mesic refugia during glacial maxima (Simpson \& Haffer, 1978). Refuge theory proposes the existence of areas of high precipitation that persisted even during the driest periods of the Pleistocene. Fragmentation of the neotropical flora and fauna into such isolated refugia is considered an important source of biological diversification in the Neotropics (Prance, 1982). 
The proposed geographical arrangement of refugia seems to account for patterns of diversification in plants (Vuilleumier, 1971; Ab'Sáber, 1977), birds (Haffer, 1969), reptiles (Vanzolini \& Williams, 1970; Haffer, 1978), butterflies (Brown, 1977) and indigenous human cultures (Meggers, 1975), but see comments of Endler (1982). All of this work has dealt exclusively with the history of mesic refugia, especially in the Amazon Basin. Geomorphological research (Bigarella \& Andrade, 1965; Bigarella, Mousinho \& da Silva, 1965; Bigarella \& Becker, 1975; Tricart, 1974, 1975; Journaux, 1975; Ab'Sáber, 1977) strongly suggests alternating periods of wet and dry conditions in southeastern Brazil, the upper Amazon, the Venezuelan llanos and northeastern Brazil. The flora present during the most mesic periods in the Amazon Basin is thought to have been of a rain forest type.

Biogeographers have begun to explore the development of Amazonian refugia in habitat types other than mesic lowland tropical forest (Andrade-Lima, 1982; Cerqueira, 1982; Haffer, 1982; Huber, 1982; Graham, 1982; Granville, 1982). An interesting proposal concerns the importance of xeric refugia in regions that today are arid or semiarid and may have been more mesic in the past (e.g. coastal Carribean, Caatinga and Chaco, see Tricart, 1974). Andrade-Lima (1982) has suggested the presence of xeric refugia in northeastern Brazil based on the fact that a number of plant species currently have disjunct distributions in the Caatinga and in the Chaco. As the present-day climate of central Brazil is moderately humid, earlier refugial formation appears to have left a legacy of disjunct populations of species that presumably had a much more extensive palaeodistribution indeed, in a sense the Caatinga of today could itself be viewed as a xeric refugium surrounded by much more mesic habitats. However, botanical evidence supports the idea that the Caatinga was divided into several smaller refugia during climatic periods that were more mesic than those obtaining today (AndradeLima, 1982). Andrade-Lima notes that, while the Caatinga flora shares numerous generic and suprageneric taxa with other plant formations, particularly the Chaco, there is a pronounced level of species endemicity in northeastern Brazil. Sarmiento (1975) shows that the Caatinga is the most dissimilar xeric region on the continent when compared floristically to the other arid and semi-arid biomes of South America.

\section{The semiarid Caatinga}

The Caatinga of northeastern Brazil consists of heterogeneous arid and semi-arid formations surrounded by more mesic phytogeographic formations. The boundary of the Caatinga closely follows the $800 \mathrm{~mm}$ isohyet, which extends from approximately $3^{\circ}$ to $16^{\circ}$ south latitude and from $35^{\circ}$ to $45^{\circ}$ west longitude (Fig. 1). The total area encompasses 650000 $\mathrm{km}^{2}$ (Reis, 1976; Frota-Pessoa et al., 1971).

The present-day climate (Nimer, 1972, 1979) shows moderate to low annual precipitation, varying from under $300 \mathrm{~mm}$ in the most arid regions to over $1600 \mathrm{~mm}$ in high plateau regions that receive orographic precipitation. Rainfall is markedly seasonal, with the driest period generally occurring between May and November. Unlike most lowland tropical areas,

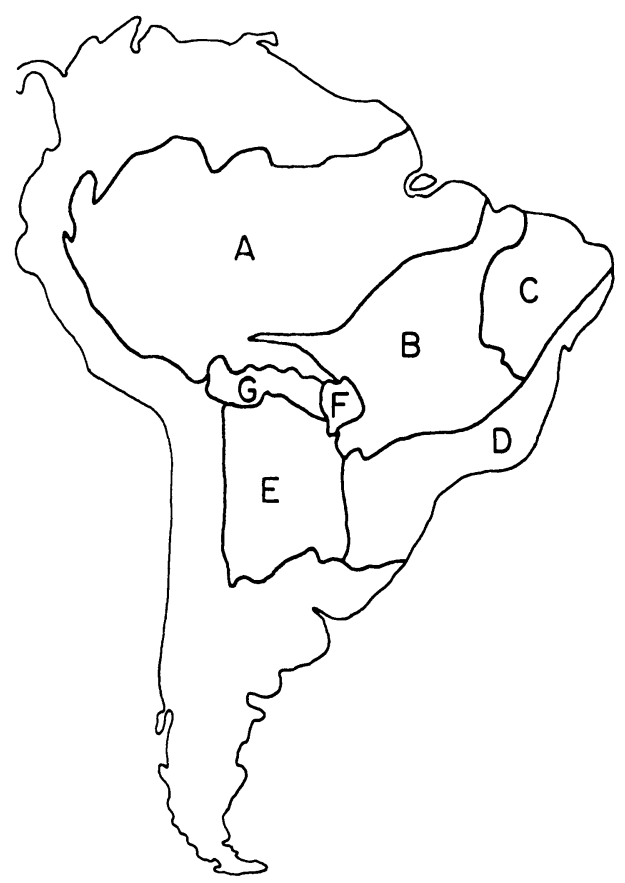

FIG. 1. The major vegetation formations that border on the Caatinga. A: Amazon Region; B: Cerrado; C: Caatinga; D: Atlantic Forest Region; E: Chaco; F: Pantanal; G: Transition between Chaco-Amazon Regions. Modified from Eiten $(1972,1974)$. 


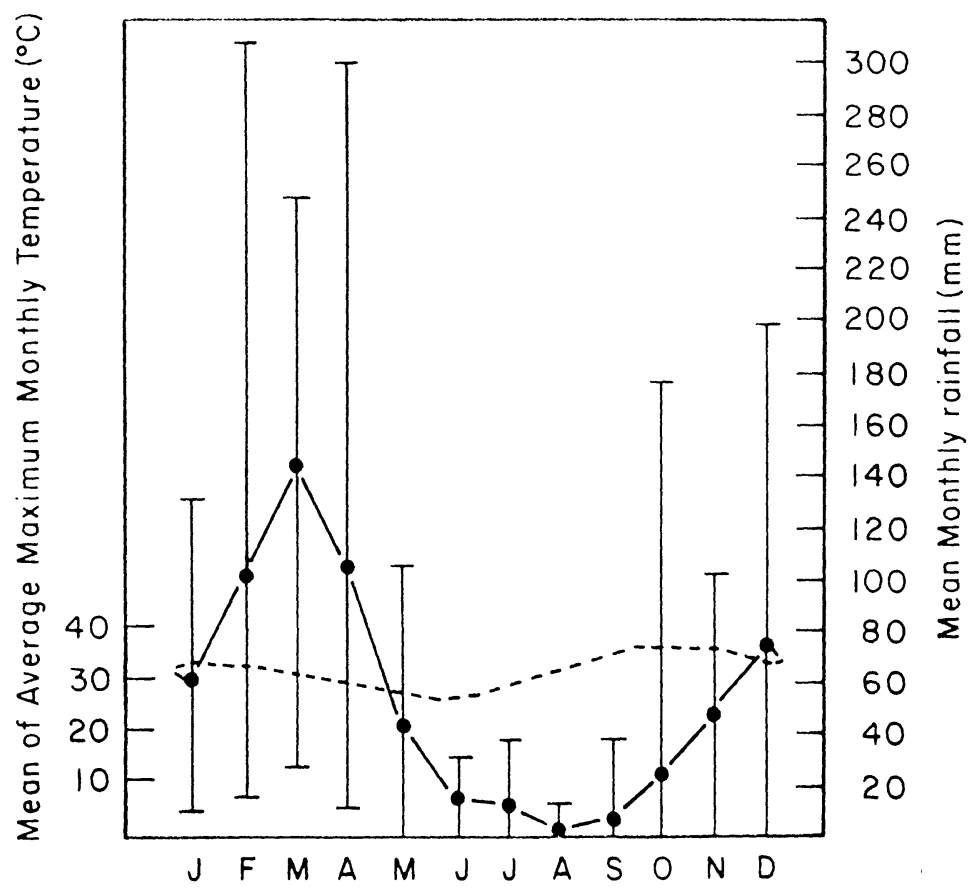

FIG. 2. Rainfall and temperature data from Ouricuri, Pernambuco, Brazil: solid line: rainfall; dashed line: temperature. Vertical lines connect end-points of ranges for rainfall data. On average, only the months of December, February, March and April show a relative water surplus. After Streilein (1982a).

the Caatinga does not exhibit a highly predictable wet-dry season. An anomalous shift in precipitation between extreme drought (with $0 \mathrm{~mm}$ rainfall per year) and severe flooding (precipitation sometimes exceeding $600 \mathrm{~mm}$ in a month) occurs throughout the Caatinga; the causes of this climatic unpredictability are unclear, but there is strong evidence that a complex of factors is involved, including shifts in the position of the Intertropical Convergence Zone, the pattern of orographic barriers, and variation in the movements of the South Atlantic Polar Front (Freise, 1938; James, 1942; Melo, 1956; Markham, 1972; Reis, 1976). The general pattern, therefore, is one of low annual rainfall with a marked dry season of severe water deficit (Fig. 2). This climatic regime is also subject to high unpredictability (Fig. 2; Streilein, 1982a). Some regions of the Caatinga (e.g. Raso da Catarina) are dry 10-11 months each year and some extensive areas may undergo rainless years (Markham, 1972).

Ab'Sáber (1970) reviewed the geomorphology of the Caatinga. A number of points are relevant to the biogeography of this area. The region is dominated by Cretaceous sandstone deposits overlying a basement of preCambrian crystalline rock. The sandstone has been eroded throughout much of the northeast, exposing the crystalline basement. This appears either as a flat rock surface that is just below the soil or as an exposed shelf, or lajeiro. In many areas, the basement is exposed as accumulations of large boulders that are extensive enough in some areas to appear as low mountainous ridges or serras. These morerugged areas produce considerable topographic relief. The Cretaceous sandstone persists only in a few localized regions where it forms extensive plateaus several hundred miles in length; the Chapada do Araripe is an example. These plateaus offer additional relief and furnish a much different substrate, both texturally and chemically. Both the plateaus and serras are important sites for orographic precipitation and, because of this, are always more mesic than the surrounding lowlands. The shallow rocky soils of the lowlands, and the presence of a non-porous crystalline base- 
ment, greatly depress the water retention capacity of the soil. When rain does fall, it is lost through rapid runoff. This problem is minimal on the sandstone chapadas, and these regions often have vegetation more typical of the Cerrado of central Brazil.

There is some question as to the true undisturbed vegetation form of the Caatinga. Webb (1974) argues that virtually all of northeastern Brazil is covered by secondary vegetation and agriculture. The influence of human alteration is most evident in the coastal areas that were formally covered by a dense diverse rainforest and are now converted almost entirely to agriculture. The area between the coastal forest and the Caatinga was once covered by a closed-canopy mata seca, or dry forest. Virtually all of this has been cut, and the region now supports agreste, an opencanopy drought deciduous scrub forest. The thorn scrub forest that is called Caatinga may also be a second growth formation. Residents of the northeast distinguish between two distinct growth forms: caatinga alta - a drought deciduous forest comprised of large trees $(10-15 \mathrm{~m})$ that form a closed canopy forest in the wet season, and caatinga baixa an open canopy thorn scrub forest with many species of cacti. Webb feels that most of the northeast was once covered by caatinga alta, and that caatinga baixa is a recent formation, occurring on land that has been heavily altered by cutting, agriculture, grazing and erosion. This view is also held by other researchers (e.g. Sarmiento, 1975).

Eiten (1972, and especially 1974) compares the Caatinga with several other xeric areas in South America (Table 1). He points out that the Caatinga's climatic distinctiveness has resulted in numerous important morphological and physiological adaptations to aridity by many species of plants. The Caatinga versus the Cerrado (the most extensive contiguous biome) has numerous cacti, terrestrial bromeliads, thorn bushes and barrel-trunked trees. Although there is an effective dry season of up to 10 months in the Caatinga (versus only 3 or 4 months in the Cerrado), rainfall unpredictability has resulted in the trees having leaves that are mesomorphic (rather than xeromorphic), and thin and soft, therefore easily shed. Coriaceous, or anatomically xeromorphic, leaves in the Caatinga would suggest adaptation to predictable drought. Moreover, leaves in the Caatinga show very rapid stomatal activity (versus very slow activity in the Cerrado), indicating further adaptations to unpredictable precipitation.

Regardless of growth form or seral stage, it is clear that the Caatinga is a vegetation formation showing specialized adaptations to unpredictable aridity among numerous species of Bromeliaceae, Euphorbiaceae, Cactaceae, and other plant families. The overall levels of specialization to unpredictable drought attest to a long history of evolution under periodically arid conditions. The high degree of endemism of much of the Caatinga's flora argues strongly for a long period of isolation under xeric conditions. The relevant point is that the Caatinga, albeit disturbed, is an historically arid region (Alvim, 1949). Andrade-Lima (1957, 1964a, b) and Andrade \& Caldas Lins (1964) present information on species composition of plants in various Caatinga habitats, as do Mares et al. (1981), Lacher (1981), Streilein (1982a) and Willig (1983).

The fauna of northeastern Brazil has only recently been studied. Vanzolini (1972, 1974, 1976) examined the lizards of the Caatinga in some detail and concluded that there is little evidence of endemism; only one species [Platynotus semitaeniatus (Iguanidae)] shows an association with Caatinga formations. In the case of Platynotus, the association may in fact reflect adaptation to exposed granitic

TABLE 1. A comparison of some climatological parameters from four of the major scrublands of South America (from Morello, 1958; Eiten, 1974).

\begin{tabular}{lllll}
\hline Biome & $\begin{array}{l}\text { Average } \\
\text { temperature }\left({ }^{\circ} \mathrm{C}\right)\end{array}$ & $\begin{array}{l}\text { Yearly } \\
\text { precipitation }(\mathrm{mm})\end{array}$ & $\begin{array}{l}\text { Drought } \\
\text { period (months) }\end{array}$ & $\begin{array}{l}\text { Variance in } \\
\text { precipitation }\end{array}$ \\
\hline Caatinga & $24-26$ & $300-1000$ & $7-10$ & Very high \\
Cerrado & $20-26$ & $750-2000$ & 5 & Very low \\
Chaco & $17-25$ & $500-1000$ & 3 & Very low \\
Monte & $16-18$ & $100-350$ & $6-9$ & Very low \\
\hline
\end{tabular}


rock formations rather than to xeric vegetation formations per se (Vanzolini, 1976; Vanzolini, Ramos-Costa \& Vitt, 1980; Vitt, 1981). Vanzolini et al. (1980) reviewed the entire fauna of reptiles of the Caatinga and concluded that 'very few' species are endemic. Sick (1965) reported that endemism in Caatinga bird species is particularly low, with probably fewer than ten or so species being limited to the Caatinga proper. This is an especially low number considering the vast size of the Caatinga. By comparison, the Cerrado (sensu latu), which is approximately 2.6 times larger than the Caatinga, contains between 118 and 148 endemic species of birds out of 935 that are listed for the Cerrado (Costa et al., 1981). However, the Caatinga shows much more endemism among birds than does the Chaco avifauna of southcentral South America, which has only one endemic species among 409 bird species in an area of $1000000 \mathrm{~km}^{2}$ (Short, 1975)! Indeed, the Chaco shares 60\% of its avifauna with the Caatinga (Short, 1975), and more than $75 \%$ of its avifauna with the Cerrado. However, when the non-mammalian vertebrate groups are examined, it seems clear that endemism in the Caatinga is relatively low, especially given the fact that botanical evidence supports the idea that the Caatinga played an important role in the development of a rather unique dry-adapted flora evolving under long-term conditions of periodic aridity.

\section{Paleoecology of northeastern Brazil}

The composition of the drought-adapted flora that is hypothesized to have spread across the Amazon Basin during dry periods has not been defined. Based upon correlations of modern floral distribution patterns and climate, most biogeographers feel that it was savanna or open woodland (e.g. Simpson \& Haffer, 1978). This assumes both a lower annual rainfall and a seasonality in precipitation. Palynological data collected at a variety of sites on the perimeter of the Basin support the hypothesis of a cycle of savanna and wet forest (Van der Hammen, 1963, 1974, 1982; Wijmstra \& Van der Hammen, 1966; Asby \& Van der Hammen, 1976).

Webb (1978) has argued convincingly from a broad review of botanical and zoological research, that a complex mix of savannas served as a corridor for colonization of southern South America by North American immigrants (see also Mares, 1985). Under this scheme, the Caatinga scrublands were a link between the savannas of Suriname, Guyana and Venezuela in the north, and the Cerrado and Chaco to the south. Webb notes that there is good evidence of shared palaeomammal faunas at disjunct points along this grassland/ scrubland corridor, as well as additional examples of herptiles and birds whose present dis tributions suggest colonization via an eastern grassland route.

Certainly, during dry periods, it would be expected that arid habitats would expand greatly at the expense of rainforest areas. As noted, the Caatinga has a very distinctive flora (Eiten, 1974; Sarmiento, 1975), although it shares numerous floral elements with the Chaco (Ducke, 1953; Rizzini, 1963; Hueck, 1972; Andrade-Lima, 1982). This raises the possibility that as the Amazon Basin became more savanna-like, the Caatinga and Chaco expanded to form a wide belt of continuous droughtdeciduous thorn scrub extending from northeastern Brazil to northern Argentina (Groot \& Groot, 1966; see also Short, 1975). During more mesic periods, the most drought-adapted portions of the Caatinga would have contracted into one or more smaller core areas (e.g. Sarmiento, 1975). These xeric refugia may have been reduced to a few very small isolated areas during especially wet periods (AndradeLima, 1982). If this had been the case, one might expect a high degree of endemism in the flora, but low rates of endemism for larger animals that require rather large geographical areas in order to maintain viable populations.

We examined the role of the Caatinga in mammalian zoogeography. We were particularly interested in studying the non-volant mammal fauna to determine the degree of endemism of Caatinga mammals as well as their levels of physiological adaptation to arid conditions. Such data should help elucidate the role of the Caatinga during the cyclic periods of mesic and xeric conditions that are currently postulated by refuge theory.

\section{Neontological evidence}

Various habitats of northeastern Brazil were examined initially in 1975 by M.A.M. 
Beginning in September 1976 surveys were conducted at a number of Caatinga localities; samples were collected in a variety of habitats. Numerous contact and transition zones were also sampled. These included the Atlantic Coastal Forest near Recife, Pernambuco; a Cerrado-Caatinga contact zone near Valenca do Piauí, Piauí, Palm Forest near Terezina, Piauí; and regional Cerrado, Cerradão and evergreen mesophytic forest on the Chapada do Araripe in Ceará state. Museum specimens in Rio de Janeiro and São Paulo, Brazil, were also examined. Detailed habitat descriptions, a gazetteer of mammal collecting localities, and complete species lists were presented in Mares et al. (1981). Complete research methods are described in the papers cited in this section.

Streilein (1982b) studied water balance in Caatinga mammals and Don Christian (pers. comm.) determined the urine concentrating capacity of the kidneys of four common
Caatinga mammals: Monodelphis domestica (Didelphidae), Thrichomys apereoides (Echimyidae), Wiedomys pyrrhorhinos (Cricetidae) and Kerodon rupestris (Caviidae).

Ecology and behaviour of non-volant Caatinga mammals were discussed in Lacher (1979, 1980, 1981), Mares et al. (1981, 1982), Lacher, Willig \& Mares (1982) and Streilein (1982a-f).

Data germane to our results were collected by Thomas E. Lacher, Jr, Michael A. Mares, Karl E. Streilein and Michael R. Willig between 1975 and 1978 as part of the Brazilian Academy of Sciences Project 'Ecology, evolution, and zoogeography of the semi-arid region of northeastern Brazil'. We collected information on the ecology, behaviour, and physiology of Caatinga mammals. Extensive systematic collections were also made (6576 specimens). One half of the collection is located at the Carnegie Museum of Natural History in

TABLE 2. Caatinga mammal species lexcluding bats, as determined by Cabrera (1957, 1960) and Mares et al. (1981)] and their distribution in other major biomes of South America

\begin{tabular}{|c|c|c|c|c|c|c|c|c|c|c|c|}
\hline \multirow[t]{2}{*}{ Taxa } & \multicolumn{5}{|c|}{ Biomes } & \multirow[t]{2}{*}{ Taxa } & \multicolumn{5}{|c|}{ Biomes } \\
\hline & A & $\mathrm{B}$ & $\mathrm{C}$ & $\mathrm{D}$ & $\mathrm{E}$ & & A & $\mathrm{B}$ & $\mathrm{C}$ & D & $\mathrm{E}$ \\
\hline Order Rodentia & & & & & & Order: Artiodactyla & & & & & \\
\hline Family: Muridae & & & & & & Family: Cervidae & & & & & \\
\hline Oryzomys eliurus & $x$ & $x$ & & & & Mazama gouazoubira & $x$ & $x$ & $x$ & $x$ & \\
\hline Oryzomys subflavus & $x$ & $x$ & & & & Ozotoceros bezoarticus & $x$ & $x$ & $x$ & $x$ & \\
\hline Rhipidomys mastacalis & $x$ & & & $x$ & & & & & & & \\
\hline Akodon arviculoides & $x$ & $x$ & $x$ & $x$ & & Order: Marsupialia & & & & & \\
\hline Bolomys lasiurus & $x$ & $x$ & & $x$ & & Family: Didelphidae & & & & & \\
\hline Calomys callosus & $x$ & $x$ & & $x$ & $x$ & Caluromys philander & & $x$ & & $x$ & \\
\hline Wiedomys pyrrhorhinos & $x$ & $x$ & & $x$ & & Monodelphis domestica & $x$ & $x$ & & $x$ & \\
\hline Family: Caviidae & & & & & & Marmosa agilis & $x$ & $x$ & $x$ & $x$ & \\
\hline Kerodon rupestris & $x$ & & & & & Marmosa cinerea & $x$ & $x$ & & $x$ & \\
\hline Galea spixii & $x$ & $x$ & & $x$ & & Marmosa karimi & $x$ & & & $x$ & \\
\hline Family: Dasy proctidae & & & & & & Order: Primates & & & & & \\
\hline Dasyprocta prymnolopha & $x$ & $x$ & & & & Family: Cebidae & & & & & \\
\hline Family: Echimyidae & & & & & & Cebus apella & $x$ & $x$ & $x$ & $x$ & \\
\hline Thrichomys apereoides & $x$ & $x$ & & & & Family: Callithricidae & & & & & \\
\hline Order: Carnivora & & & & & & Callithrix jacchus & $x$ & $x$ & & $x$ & \\
\hline Family: Canidae & & & & & & Order: Edentata & & & & & \\
\hline Cerdocyon thous & $x$ & $x$ & $x$ & $x$ & & Family: Myrmecophagidae & & & & & \\
\hline $\begin{array}{l}\text { Family: Procyonidae } \\
\text { Procyon cancrivorous }\end{array}$ & $x$ & $x$ & $x$ & $x$ & & $\begin{array}{l}\text { Tamandua tetradactyla } \\
\text { Family: Dasy podidae }\end{array}$ & $x$ & $x$ & $x$ & $x$ & \\
\hline Family: Mustelidae & & & & & & Dasypus novemcinctus & $x$ & $x$ & $x$ & $x$ & \\
\hline Galictis vittata & $x$ & $x$ & $x$ & $x$ & $x$ & Euphractus sexcinctus & $x$ & $x$ & $x$ & $x$ & \\
\hline Conepatus semistriatus & $x$ & $x$ & $x$ & $x$ & & Tolypeutes tricinctus & $x$ & $x$ & & & \\
\hline Family: Felidae & & & & & & & & & & & \\
\hline Felis concolor & $x$ & $x$ & $x$ & $x$ & $x$ & Order: Lagomorpha & & & & & \\
\hline Felis onca & $x$ & $x$ & $\mathrm{x}$ & $x$ & & Family: Leporidae & & & & & \\
\hline Felis yagouaroundi & $x$ & $x$ & $x$ & $x$ & & Sylvilagus brasiliensis & $x$ & $x$ & $x$ & $x$ & \\
\hline
\end{tabular}

$\mathrm{A}=$ Caatinga $; \mathrm{B}=$ Cerrado $; \mathrm{C}=$ Chaco $; \mathrm{D}=$ Evergreen Mesophytic Forest $\mathrm{E}=$ Pampa. 
Pittsburgh, Pennsylvania, and the other half is located at the Museu de Zoologia of the Universidade de São Paulo, São Paulo, Brazil.

We prepared a list of non-volant Caatinga mammal species based upon our own collections and examination of museum specimens
(Table 2). We indicate their distribution in the five major ecosystem types of northeastern Brazil. Only Kerodon rupestris is restricted to the Caatinga. Within the Caatinga, Kerodon occurs only in rocky outcrops, boulder piles, or on serras of exposed crystalline basement.

TABLE 3. Degree of adaptation to aridity by small mammals from major xeric regions of the world

\begin{tabular}{|c|c|c|c|c|c|}
\hline Location & Classification & Locomotion & $\begin{array}{l}\text { Relation to } \\
\text { free water }\end{array}$ & $\begin{array}{l}\text { Maximum } \\
\text { osmotic } \\
\text { concentra- } \\
\text { tion of urine } \\
(\text { mosmol/1) }\end{array}$ & Source \\
\hline
\end{tabular}

Africa

Rodentia
Dipodidae
Jaculus
Muridae
Gerbillus

Australia

Rodentia

Muridae

Notomys

Leggadina

Marsupialia

Macropodidae

Macropus

Bipedal

Undetermined

$3500-$ 4000

$4920-$

9370

8970

Quadrupedal

Independent

500

5500

(1964)

Schmidt-Nielsen

(1964)

MacMillen \& Lee (1967)

MacMillen et al.

(1972)

Derry \& Dawson cited by Hulbert \& Dawson (1974)

North America

Rodentia

Heteromyidae

Dipodomys

Perognathus

South America- Rodentia

Caatinga

Murida

Wiedomys Quadrupedal

Dependent

2542

Dependent

Caviidae

Kerodon

Galea

Echimyidae

Thrichomys

Marsupialia

Didelphidae

Monodelphis

Quadrupedal

Dependent

3285
Schmidt-Nielsen

et al. (1948)

MacMillen (1964)
D. P. Christian

(pers. comm.)

Streilein (1982b)

2119

D. P. Christian

(pers. comm.)

Streilein (1982b)

D. P. Christian

(pers. comm.)

D. P. Christian

(pers. comm.)

South America- $\quad$ Rodentia

Monte Desert

Muridae

$\begin{array}{lll}\text { Eligmodontia Quadrupedal Dependent } 5763 & \begin{array}{l}\text { Mares (1975a, } \\ 1977 \mathrm{a})\end{array}\end{array}$

Calomys

Quadrupedal

Independent

5183

Mares (1977b) 
Kerodon has numerous morphological, ecological and behavioural adaptations for its saxicolous existence (Lacher, 1980, 1981; Mares \& Lacher, ms.).

A number of species are distributed throughout the Caatinga-Cerrado region (Table 2). Many of these (e.g. Oryzomys eliurus, O. subflavus and Calomys callosus) are agricultural commensals. In the vicinity of Exu, Pernambuco, these species occur in an edaphic form of Cerrado vegetation on the Chapada do Araripe, and move down into lowland Caatinga thorn scrub through corridors of agricultural land and disturbed forest (Streilein, 1982a). They are not found in thorn scrub in the absence of adjacent agriculture. Although they are found in the Caatinga region, by microhabitat preference they are clearly not Caatinga mammals.

None of the Caatinga mammals shows any pronounced physiological adaptations to aridity (Table 3 ). This is an unusual situation compared to other arid-region mammals (e.g. Mares, 1976, 1980, 1983). Kerodon rupestris, the only Caatinga endemic, has kidneys that are the least efficient concentrators of urine of any of the species tested (Don Christian, pers. comm.). When several species of Caatinga rodents are compared with rodents from more arid areas, it is evident that the former are less able to concentrate urine and to exist without free water in the diet. Unfortunately, data on urine concentrating abilities of South American species from more mesic habitats are not available. Species from the Monte Desert of Argentina, however, are shown to be much more adept at water conservation than are the Caatinga species.

\section{Discussion}

The results obtained for mammals corroborate the observations of Sick (1965; see also Short, 1975) on birds and Vanzolini (1974, 1976; Vanzolini et al., 1980) on reptiles. There is no characteristic Caatinga mammal fauna. In contrast to the high degree of species endemicity in the Caatinga flora (Andrade-Lima, 1982), the vertebrate fauna is largely a subset of the Cerrado and Atlantic Coastal Forest faunas. Both of these vegetation formations are substantially more mesic than the Caatinga, and neither shows the climatic irregularity that distinguishes the Caatinga.

Data on physiological adaptations to aridity support the contention that the Caatinga mammal fauna reflects an origin in more mesic vegetation formations. None of the six common rodent species examined were water independent. The four species that were examined for urine concentrating ability showed very low values for osmotic concentration. It must be remembered that the Caatinga is subject to extreme drought for extended periods of time. Recently there has been little or no rain throughout much of the Caatinga for almost 4 years, a fact that has led to great human suffering over a vast region. Thus, while it appears that the rodent species examined show the expected levels of urine concentrating ability given the mean annual precipitation of the Caatinga (Fig. 3), water independence would clearly be advantageous

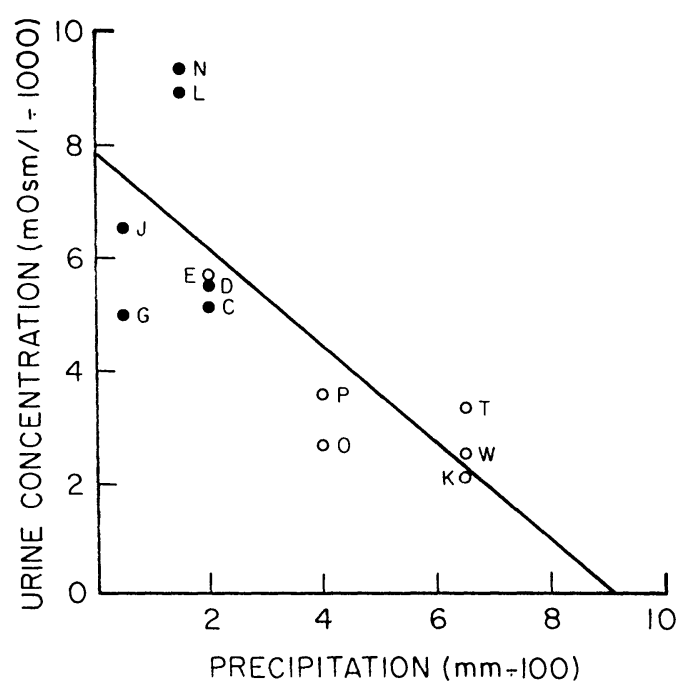

FIG. 3. The relationship between urine concentrating ability and regional annual precipitation, for three Caatinga species $(\mathrm{K}=$ Kerodon, $\mathrm{W}=$ Wiedomys, $\mathrm{T}=$ Thrichomys $)$; four Monte Desert species $(\mathrm{O}=$ Oryzomys longicaudatus, $\mathrm{P}=$ Phyllotis darwini, $\mathrm{C}=$ Calomys musculinus, $\mathrm{E}=$ Eligmodontia $)$; North American Dipodomys (D); Australian Leggadina (L) and Notomys (N); and African Jaculus (J) and Gerbillus (G). Urine concentrations from Table 3 and Mares (unpublished); precipitation data from various sources. The slope is -8.638 and $F[1,10]=$ $18.9, P<0.005$. Solid circles indicate water independence, while open circles are species that are dependent upon free water. 
during the recurring droughts. The shift toward water independence has not occurred, however. The appearance of water independence in Argentine (Fig. 3) and Peruvian (Koford, 1968) desert mice indicates that there is no phylogenetic roadblock to impede the development of this trait among South American species (although it has yet to be demonstrated for any hystricognath species, probably due to the lack of physiological research on the continent). Rodents in other semi-arid areas on other continents do show an ability to exist without free water (e.g. see Schmidt-Nielsen, 1964; MacMillen, 1964, 1983; Mareș, 1973, 1983).

The Caatinga mammal fauna is clearly neither endemic nor arid adapted. Most of the species also occur in the Cerrado. Many 'Caatinga' mammals do not, in fact, occur in Caatinga habitats, even though they are found within the geographical limits of the Caatinga. The number of species of small non-volant mammals that is found in any abundance in thorn scrub habitats is only five (Mares et al., 1981; Streilein, 1982a). Thus the Caatinga proper supports one of the most depauperate small mammal faunas in the tropics. Streilein (1982c), for example, found that densities of small mammals may be so reduced that only one individual of a species will be captured in more than 29000 trap nights. This is an important point. The overall impression of mammal abundance in the Caatinga is that of a marked scarcity. Indeed, we are not aware of data that indicate a density value as low as that of the Caatinga in any other semi-arid or arid region. Even the extremely low densities described by Mares et al. (1977) for the Monte Desert are much higher than those which were found in the Caatinga. Small mammal densities in Salta Province, Argentina, in the driest portions of the Chaco, while low, are likewise much higher than those of the Caatinga (Mares, unpublished).

Of the five species that occur in thorn scrub (Monodelphis domesticus, Thrichomys apereoides, Galea spixii, Kerodon rupestris, Wiedomys pyrrhorhinus), all but Wiedomys attain their highest densities in association with granitic outcrops, boulder piles or serras (Lacher, 1981; Streilein, 1982c, d). Because of the presence of deep crevices and rocky soil, these areas remain green and mesic well into the dry season (Lacher, 1981; Mares et al., 1981). Our data suggest that the small mammals of the Caatinga continue to inhabit the region by persisting in these mesic enclaves during the extensive droughts of irregular periodicity (Streilein, 1982c, d). During the moist portions of the year (or during successive years of elevated precipitation), these species recolonize the thorn scrub, only to diminish once again in times of reduced rainfall. Since there are numerous such microclimatic refugia of varying size scattered throughout the Caatinga, however, these species are able to withstand the xeric periods and once again recolonize the plains. Thus we hypothesize that a boom and bust pattern of population expansion and retraction will be shown to characterize many of the small mammals of this region. Even the volant mammals (bats), which are the largest contributors to species diversity in the Caatinga, are largely restricted to the rocky hills supporting moist forests (Willig, 1982, 1983). In effect, the small mammal fauna of the Caatinga possesses characteristics generally indicative of life in a more mesic environment. This is so because the persistence of each species in the region is accomplished in a fairly mesic microenvironment, while widespread colonization also occurs during mesic times of the year.

If the area currently occupied by the Caatinga had been reduced to one or more arid refugia during the Pleistocene, it might be expected that there would be a pronounced level of endemism (or at least that there would be more than a single endemic species). Furthermore, mammal species which had evolved in such xeric refugia should posses physiological and/or morphological adaptations characteristic of other arid-zone vertebrates. Such specializations to aridity might further restrict Caatinga species to the semi-arid portions of the region. The absence of pronounced physiological adaptations to aridity by mammals, the generally low level of vertebrate endemism, and the importance of mesic enclaves in maintaining populations during dry periods, argue against the suggestion (Müller, 1973) that large Pleistocene refugia significantly influenced speciation patterns of vertebrates in the Caatinga. Small xeric islands probably did form several times somewhere in this vast region, but their presence today is 
detectable only among species of low vagility, such as the plants. Had such refugia formed repeatedly in the Caatinga, a species elimination mechanism (Mares, 1979) would very likely have been in operation. Species seeking refuge in these habitats would have died out over time due to small population size. Whether or not this occurred, or how many species might have been involved, is unknown. However, lowered diversity, rather than elevated numbers of species, would have been the ultimate result.

Any scenario dealing with the biogeographic history of the Caatinga contains an additional complicating factor, the anomalous drought. If the climate of the Caatinga was as unpredictable in the past as it is today, small mammals would have faced a formidable task in adapting to life in xeric refugia. It is unlikely that short-lived vertebrates of low vagility could have evolved adaptations to deal with an aridity that appeared irregularly at intervals much greater than the generation time of any particular species. Thus several generations of animals would experience strong selection pressures favouring adaptations related to life in a mesic forest, while the descendents of these animals would be subjected to sudden selection pressures favouring the opposite extreme of the climatic scale. Adaptations for life in a moist tropical habitat would be illsuited to the hot, dry, leafless environment that would suddenly occur over huge areas and persist for years. Since the ancestors of species currently found in the Caatinga were most probably colonizers from the surrounding mesic biomes (Mares et al., 1981), they may well have only been able to persist in the region by becoming mesic microhabitat specialists. Indeed, specialization to aridity may have proven counterproductive during the years, or even decades, of elevated precipitation that characterize the region today. As such, it may be almost impossible for these species to consolidate adaptations for the extensive arid habitats which appear randomly through time.

Thus, we have two alternative hypotheses concerning the biogeographic history of the area. The first proposes the existence of Pleistocene refugia that influenced speciation patterns. Evidence from plants and possibly insects supports this idea, but the low verte- brate endemism does not. Even some of the few endemic Caatinga birds (e.g. the trochilids Augastes scutatus and A. lumachellus) inhabit rocky areas rather than the dry plains (Sick, 1965). Largely because of the plant data and the geomorphology of the region, we support the idea that xeric Caatinga refugia have formed in the past and we expect that additional research on invertebrates and other species capable of extended periods of dormancy will reveal numerous endemic species. However, we feel that the unusual climate of the Caatinga has obviated specialization by vertebrates, given the fact that they have relatively long life spans and relatively low reproductive rates coupled with an inability to undergo prolonged dormancy. They persist in the Caatinga by inhabiting its climatic interstices, those microhabitats that retain moisture throughout the year. Our data suggest that adaptations among the small mammals have developed toward the mesic end of the spectrum (the climate that most commonly obtains in the Caatinga) and thus do not parallel those of the flora of the region. This has resulted in the curious situation of a largely mesic-adapted tropical fauna inhabiting a region distinctive for its aridity and droughtadapted flora.

\section{Conclusions}

The Caatinga has many endemic species of xeric adapted plants, although there are few endemics at the generic level (Andrade-Lima, 1982). The flora seems to be derived from the Chaco (Andrade-Lima, 1982) and to a lesser degree from the dry Carribean flora (Sarmiento, 1975).

The Caatinga vertebrate fauna is depauperate, contains few endemics, and has no mammals adapted to arid conditions (Sick, 1965; Vanzolini, 1974, 1976; Mares et al., 1981). It is essentially a subset of the Cerrado fauna.

We propose that, like the Monte Desert in Argentina (Mares, 1975b, 1976, 1979, 1980), the arid parts of the Caatinga contracted into numerous small refugia as the savanna/woodland expanded northwards during mesic periods. Small refugia, coupled with the irregular droughts of northeastern Brazil, precluded the development of an arid adapted 
vertebrate fauna. Present sites of orographic rainfall served as refugia for more mesic adapted Cerrado species during glacial maxima, and serve a similar refugial function during the unpredictable extensive droughts that characterize the region today. Most Caatinga endemics are, in fact, primarily species that developed in the mesic refuges, not in the xeric ones, and the microhabitats they inhabit today reflect such a history.

\section{Acknowledgments}

This work was supported by a federal grant (FINEP) to the Brazilian Academy of Sciences (Project number 85: 'Ecology, evolution and zoogeography of the semi-arid region of northeastern Brazil'). Additional funds were provided by the Carnegie Museum of Natural History. Dr Karl Streilein was involved in all aspects of Brazilian field work. Dr L. J. Vitt generously aided us in various aspects of field research. Dr Ernst Mayr made many helpful comments on an earlier version of this manuscript. We would also like to express our gratitude to $\mathrm{Dr}$ Aristedes $\mathrm{P}$. Leão and $\mathrm{Dr}$ Paulo E. Vanzolini; without their personal concern for this project, it would not have been successful. Dr Don Christian kindly allowed us to use his physiological data on Caatinga rodents.

\section{References}

Ab'Sáber, A.N. (1970) Provincías géologicas e domínios morfoclimáticos no Brazil. Univ. $S$. Paulo, Inst. Geogr., Geomorfologia, 20, 1-26.

Ab'Sáber, A.N. (1977) Espaços ocupados pela expansão dos climas secos na América do Sul, por ocasião dos períodos glacia is quaternários. Paleoclimas, 3, 1-19.

Alvim, P. de T. (1949) Observações ecologicas sobre flora da região semi-árida do Nordeste. Rev. Ceres Vicosa, 8, 105-111.

Andrade-Lima, D. de (1957) Estudos fitogeográficos de Pernambuco. Inst. Pesquisas Agron. Pernambuco Publ. 2.

Andrade-Lima, D. de (1964a) Esboço fitoecológico de alguns 'brejos' de Pernambuco. Inst. Agron. Nova Sér. Public. Bol. Tecn. 8.

Andrade-Lima, D. de (1964b) Contribuição a dinâmica da flora do Brasil. Univ. Recife Arq. Inst. Ciênc. da Terra, 2, 15-20.

Andrade-Lima, D. de (1982) Present-day forest refuges in northeastern Brazil. In: Biological diversification in the tropics (ed. by G. T. Prance), pp. 245-251. Columbia University Press, New York.
Andrade, G.O. de \& Caldas Lins, R. (1964) Introdução ao estudo dos 'brejos' pernambucanos. Univ. Recife Arq. Inst. Ciênc. da Terra, 2, 21-34.

Asby, M.L. \& Van der Hammen, T. (1976) Some paleoecological studies of Rondônia, southern part of the Amazon Basin. Acta Amazônica, 6, 293-299.

Bigarella, J.J. \& Andrade, G.O. de (1965) Contributions to the study of the Brazilian Quaternary. Geol. Soc. Am. Spec. Pap. 184, 433-451.

Bigarella, J.J. \& Becker, R.D. (1975) Topics for discussion. International Symposium of the Quaternary (Southern Brazil, July 15-31, 1975). Bol. Paranaense Geoscienc. 33, 171-275.

Bigarella, J.J., Mousinho, M.R. \& da Silva, J.X. (1965) Processes and environments of the Brazilian Quaternary. Conselho Pesq. Univ. Paraná and Com. Planejamento Econ. Estad. Paraná, Curitiba, Paraná.

Brown, K.S., Jr (1977) Geographical patterns of evolution in Neotropical forest Lepidoptera (Nymphalidae: Ithomiinae and NymphalinaeHeliconini). Biogéographie et evolution en Amerique tropicale (ed. by $\mathrm{H}$. Descimon), pp. 1 18-160. Lab. Zool. Ecole Norm. Sup., Paris.

Cabrera, A. (1957) Catálogo de los mamíferos de América del Sur. I. (Metatheria-UnguiculataCarnivora). Rev. Mus. Argent. Cienc. Natur. 'Bernardino Rivadavia', Zool. 4, 1-307.

Cabrera, A. (1960) Catálogo de los mamíferos de América del Sur. II. (Sirenia-PerissodactylaArtiod actyla - Lagomorpha - Rodentia - Cetacea) Rev. Mus. Argent. Cienc. Natur. 'Bernardino Rivadavia', Zool. 4, 309-732.

Cerqueira, R. (1982) South American landscapes and their mammals. Mammalian biology in South America (ed.by M. A. Mares and H.H. Genoways), pp. 53-75. Pymatuning Laboratory of Ecology Spec. Publ. No. 6, Linesville, Pennsylvania.

Costa, C.C.C. da, Lima, J.P. de, Cardoso, L.D. \& Henriques, V.Q. (1981) Fauna do Cerrado, Lista Preliminar de Aves, Mamíferos y Répteis. Fund. Inst. Bras. de Geogr. y Estatist. Serie Rec. Nat. y Meio Amb., 6, Rio de Janeiro, Brazil.

Ducke, A. (1953) As leguminosas de Pernambuco e Paraiba. Mem. Inst. Osw. Cruz, 51, 417-461.

Eiten, G. (1972) The cerrado vegetation of Brazil. Bot. Rev. 38, 205-341.

Eiten, G. (1974) An outline of the vegetation of South America. Proc. 5th Cong. Internat. Primat. Soc., Nagoya, Japan, pp. 529-545.

Endler, J.A. (1982) Pleistocene forest refuges: fact or fancy? Biological diversification in the tropics (ed. by G. T. Prance), pp. 64i-657. Columbia University Press, New York.

Freise, F.W. (1938) The drought region of northeastern Brazil. Geog. Rev. 28, 363-378.

Frota-Pessoa, O., Coutinho, A.B., Andrade-Lima, D. de, Furtado, A.F., Lima, M.J.A., Pereira, S.M. \& Mansur, E.A. (1971) Biologia Nordeste I. ecologia $e$ taxonomia. Univ. Federal de Pernambuco, Recife.

Graham, A. (1982) Diversification beyond the Amazon Basin. Biological diversification in the 
tropics (ed.by G. T. Prance),pp. 78-90. Columbia University Press, New York.

Granville, J.J. de (1982) Rain forest and xeric flora refuges in French Guiana. Biological diversification in the tropics (ed. by G.T. Prance), pp. $159-$ 181. Columbia University Press, New York.

Groot, J.J.\& Groot, C.R. (1966) Pollen spectra from deep sea sediments as indicators of climatic changes in southern South America. Marine Geol. 4, 525-537.

Haffer, J. (1969) Speciation in Amazonian forest birds. Science, 165, 131-137.

Haffer, J. (1978) Quaternary biogeography of tropical lowland South America. The South American herpetofauna: its origin, evolution and dispersal (ed. by W. E. Duellman), pp. 107-140. University of Kansas Press, Lawrence.

Haffer, J. (1982) General aspects of the refuge theory. Biological diversification in the tropics (ed. by G. T. Prance), pp. 6-24. Columbia University Press, New York.

Huber, O. (1982) Significance of savanna vegetation in the Amazon Territory of Venezuela. Biological diversification in the tropics (ed. by G. T. Prance), pp. 221-244. Columbia University Press, New York.

Hueck, K. (1972) As Florestas da América do Sul. Edit. Univ. Brasília-Ed. Polígono, São Paulo.

Hulbert, A.J. \& Dawson, T.J. (1974) Water metabolism in perameloid marsupials from different environments. Comp. Biochem. Physiol. 47A, 617-633.

James, P.E. (1942) Latin America. Odyssey Press, New York.

Journaux, A. (1975) Recherches géomorphologiques en Amazonie brésilienne. Cent. Nat. Res. Sci. Cent. Géomorphol. de Caen Bol. 20, 3-68.

Koford, C.B. (1968) Peruvian desert mice: water independence, competition, and breeding cycle near the equator. Science, 160, 552-553.

Lacher, T.E., Jr (1979) Rates of growth in Kerodon rupestris and an assessment of its potential as a domesticated food source. Papeis Avulsos Zool. (S. Paulo), 33, 67-76.

Lacher, T.E., Jr (1980) The comparative social behavior of Kerodon rupestris and Galea spixii in the xeric Caatinga of northeastern Brazil. Ph.D. thesis, University of Pittsburgh.

Lacher, T.E., Jr (1981) The comparative social behavior of Kerodon rupestris and Galea spixii and the evolution of behavior in the Caviidae. Bull. Carnegia Mus. nat. Hist. 17, 1-71.

Lacher, T.E., Jr, Willig, M.R. \& Mares, M.A. (1982) Food preference as a function of resource abundance with multiple prey types: an experimental analysis of optimal foraging theory. Am. Nat. 120,297-316.

MacMillen, R.E. (1964) Population ecology, water relations, and social behavior of a southern California semi-desert rodent fauna. Univ. Calif. Publ. Zool. 71, 1-66.

MacMillen, R.E. (1983) Water regulation in Peromyscus. J. Mammal. 64, 38-47.

MacMillen, R.E., Baudinette, R.V. \& Lee, A.K. (1972) Water economy and energy metabolism of the sandy inland mouse, Leggadina hermannsburgensis. J. Mammal. 53, 529-539.

MacMillen, R.E. \& Lee, A.K. (1967) Australian desert mice: independence of exogenous water. Science, 158, 383-385.

Mares, M.A. (1973) Climates, mammalian communities and desert rodent ad aptations: an investigation into evolutionary convergence. Ph.D. thesis, University of Texas at Austin.

Mares, M.A. (1975a) Observations of Argentine desert rodent ecology, with emphasis on water relations of Eligmodontia typus. In: Rodents in desert environments (ed. by I. Prakash and P. K. Ghosh), pp, 155-175. Junk B.V., The Hague, The Netherlands.

Mares, M.A. (1975b) South American mammal zoogeography: evidence from convergent evolution in desert rodents.Proc. Nat. Acad. Sci. U.S.A. 72, $1702-1706$.

Mares, M.A. (1976) Convergent evolution of desert rodents: multivariate analysis and zoogeographic implications. Paleobiology, 2, 39-63.

Mares, M.A. (1977a) Water economy and salt balance in a South American desert rodent, Eligmodontia typus. Comp. Biochem. Physiol. 56A, 325-332.

Mares, M.A. (1977b) Water independence in a nondesert South American rodent. J. Mammal. 58, $653-656$.

Mares, M.A. (1979) Small mammals and creosotebush: patterns of richness. Larrea (ed. by E. C. Lopez, T. J. Mabry and S. F. Tavizon), pp. 5794. Centro de Investigación en Química Aplicada, Saltillo, Coahuila, México.

Mares, M.A. (1980) Convergent evolution among desert rodents: a global perspective. Bull. Carnegie Mus Nat. Hist. 16, 1-51.

Mares, M.A. (1983) Desert rodent adaptation and community structure. Biology of desert rodents (ed. by O. J. Reichman and J. H. Brown). Great Basin Naturalist, 7, 30-43.

Mares, M.A. (1985) The effects of the Great American Interchange on the mammal faunas of xeric habitats. The great American biotic interchange (ed. by F. Stehli and S. D. Webb). Plenum Press, New York.

Mares, M.A., Blair, W.F., Enders, F.A., Greegor, D., Hunt, J., Hulse, A.C., Otte, D., Sage, R. \& Tomoff, C. (1977) The strategies and community patterns of desert animals. Convergent evolution in warm deserts (ed. by G. H. Orians and O. T. Solbrig), pp. 107-163. Dowden, Hutchinson and Ross Inc., Stroudsburg, Pennsylvania.

Mares, M.A., Streilein, K.E. \& Kosco, M.P. (1982) Nonsynchronous molting in three genera of tropical rodents from the Brazilian Caatinga (Thrichomys, Galea, and Kerodon). J. Mammal. 63, 484-488.

Mares, M.A., Willig, M.R., Streilein, K.E. \& Lacher, T.E., Jr (1981) The mammals of northeastern Brazil: a preliminary assessment. Ann. Carnegie Mus. 50, 80-137.

Markham, C.G. (1972) Aspectos climatológicos da seca no Brasil-Nordeste. Sudene Assessouria Técnica, Divisão de Documentação, Recife.

Meggers, B.J. (1975) Application of the biological 
model of diversification to cultural distributions in tropical lowland South America. Biotropica, 7, $141-161$.

Melo, M.L. de (1956) Excursion Guidebook, No. 7 Northeast. Eighteenth International Geographical Congress, Brazil.

Morello, J. (1958) La provincia fitogeografica del Monte. Opera Lilloana, 2, 1-155.

Müller, P. (1973) The dispersal centres of terrestrial vertebrates in the neotropical realm, Vol. II. Dr. W. Junk B.V., The Hague, The Netherlands.

Nimer, E. (1972) Climatologia da região Nordeste do Brasil: introduçã á climatologia dinâmica. Rev. Bras. Geogr. 34, 3-51.

Nimer, E. (1979) Climatologia do Brasil. Supren, Rio de Janeiro.

Prance, G.T. (Ed.) (1982) Biological diversification in the tropics. Columbia University Press, New York.

Reis, A.C. de Souza (1976) Clima da Caatinga. An. Acad. Brasil. Ciẽnc. 48, 325-335.

Rizzini, C.T. (1963) Nota prévia sobre a divisão fitogeográfica do Brasil. Revta Bras. Geogr. 25, $1-64$.

Sarmiento, G. (1975) The dry plant formations of South America and their floristic connections. J. Biogeogr. 2, 233-251.

Schmidt-Nielsen, B., Schmidt-Nielsen, K., Brokaw, A. \& Schneiderman, H. (1948) Water conservation in desert rodents. J. cell. comp. Physiol. 32, $331-360$.

Schmidt-Nielsen, K. (1964) Desert animals. Clarendon Press, Oxford.

Short, L.L. (1975) A zoogeographic analysis of the South American Chaco avifauna. Bull. Amer. Mus. Nat. Hist. 154, 163-352.

Sick, H. (1965) A fauna do Cerrado. Arq. de Zool., S. Paulo, 12, 71-93.

Simpson, B.B. \& Haffer, J. (1978) Speciation patterns in the Amazonian forest biota. Ann. Rev. Ecol. Syst. 9, 497-518.

Streilein, K.E. (1982a) Ecology of small mammals in the semiarid Brazilian Caatinga. I. Climate and faunal composition. Ann. Carnegie Mus. 51, 79-107.

Streilein, K.E. (1982b) Ecology of small mammals in the semiarid Caatinga. II. Water relations. Ann. Carnegie Mus. 51, 109-126.

Streilein, K.E. (1982c) The ecology of small mammals in the semiarid Brazilian Caatinga. III. Reproductive biology and population ecology. Ann. Carnegie Mus. 51, 251-269.

Streilein, K.E. (1982d) The ecology of small mammals in the semiarid Brazilian Caatinga. IV. Habitat selection. Ann. Carnegie Mus. 51, 331-343.

Streilein, K.E. (1982e) The ecology of small mammals in the Brazilian Caatinga. V. Agonistic behavior and overview. Ann. Carnegie Mus. 51, 345-369.

Streilein, K.E. (1982f) Behavior, ecology, and distribution of South American marsupials. Mammalian biology in South America (ed. by M. A. Mares and H. H. Genoways), pp. 231-250.
Pymatuning Laboratory of Ecology Spec. Publ. No. 6, Linesville, Pennsylvania.

Tricart, J. (1974) Existence de périodes sèches au Quaternaire en Amazonie et dons les régions voisines. Rev. Geomorphol. Dynam. 4, 145-158.

Tricart, J. (1975) Influence des oscillations climatique récentes sur le modelé en Amazonie Orientale (Region de Santarém) d'après les images radar latéral. Z. Geomorphol. N.F. 19, 140-163.

Van der Hammen, T. (1963) A palynological study of the Quaternary of British Guiana. Leidse Geol. Meded. 29, 125-180.

Van der Hammen, T. (1974) The Pleistocene changes of vegetation and climate in tropical South America. J. Biogeogr. 1, 3-26.

Van der Hammen, T. (1982) Paleoecology of tropical South America. Biological diversification in the tropics (ed.by G. T. Prance), pp. 60-66. Columbia University Press, New York.

Vanzolini, P.E. (1972) Miscellaneous notes on the ecology of some Brasilian lizards (Sauria). Papéis Avulsos Zool., S. Paulo, 26, 83-115.

Vanzolini, P.E. (1974) Ecological and geographical distribution of lizards in Pernambuco, north eastern Brasil (Sauria). Papéis Avulsos Zool., S Paulo, 28, 61-90.

Vanzolini, P.E. (1976) On the lizards of a CerradoCaatinga contact: evolutionary and zoogeographical implications (Sauria). Papéis Avulsos Zool., S. Paulo, 29, $111-119$.

Vanzolini, P.E., Ramos-Costa, A.M.M. \& Vitt, L.J. (1980) Repteis das Caatingas. Academia Brasileira de Ciencias, Rio de Janeiro, Brazil.

Vanzolini, P.E. \& Williams, E.E. (1970) South American anoles: the geographic differentiation and evolution of the Anolis chrysolepis species group (Sauria, Iguanidae). Arq. Zool., S. Paulo, $19,1-240$.

Vitt, L.J. (1981) Lizard reproduction: habitat specificity and constraints on relative clutch mass. Am. Nát. 117, 506-514.

Vuilleumier, B. (1971) Pleistocene changes in the fauna and flora of South America. Science, 173, $771-780$.

Webb, K. (1974) The changing face of northeast Brazil. Columbia University Press, New York.

Webb, S.D. (1978) A history of savanna vertebrates in the New World. Part II: South America and the Great Interchange. Ann. Rev. Ecol. Syst. 9, 393-426.

Wijmstra, T.A. \& Van der Hammen, T. (1966) Palynological data on the history of tropical savannas in northern South America. Leidse Geol. Meded. 38, $71-90$.

Willig, M.R. (1982) A comparative ecological study of Caatingas and Cerrado chiropteran communities: composition, structure, morphometrics and reproduction. Ph.D. thesis, University of Pittsburgh.

Willig, M.R. (1983) Composition, microgeographic variation, and sexual dimorphism in Caatingas and Cerrado bat communities from Northeast Brazil. Bull. Carnegie Mus. nat. Hist. 23, 1-131. 